\title{
Factors Affecting Students Decision Making In Accommodation Process of University
}

\author{
Zairina Ibrahim, Normy Rafida Abdul Rahman, Md Gapar Md Johar
}

\begin{abstract}
The hostels accommodation assumes a critical job in the hotel business all through the world and even in a few areas in Malaysia. Be that as it may, in numerous spots in Malaysian hostels have yet to be presented. They can possibly offer spending lodging accommodation, yet inns and motels remain the most prevalent types of cabin. A center gathering was utilized to pick up understanding into students' impression of hostels and helped in the advancement of a composed study. It was sent to a haphazardly chosen test of 215 university students. There was a reaction rate of $8 \%(n=401)$. Respondents thought about hostels and were ready to remain in them. Therefore, a factor investigation was led on 31 attributes of hostels that may be imperative to hostel clients and it was confirmed that these things could be decreased to three factors: Safety and Amenities $(\alpha=.92)$, Area and Socializing ( $\alpha=.91)$, and Accommodations $(\alpha=60)$.In fact, well-being and Amenities had the most elevated mean scores for individual things in the factor while Accommodations had the least. The various straight relapse was utilized to decide whether the three factors would foresee university students 'plan to remain in a hostel. The relapse demonstrate was huge ( $p \leq 000)$ and every one of the three factors were noteworthy. The model had a $R$ Square of .31. A t-test was utilized to decide whether guys and females contrasted in goal to remain in a hostel, Protection issue, Room Sharing, Security, Cleanliness Issue and Freedom. However, females had higher mean scores for Room Sharing than guys. This examination demonstrated that undergrads would remain in a hostel. The hostel proprietors/administrators what's more, hostel associations can utilize this data to more readily showcase their hostel and it will help them to figure out which luxuries they should need to meet client requests. Research ought to be led with a bigger and all the more geologically various example to decide whether the results can be summed up past university students. Nonetheless, research with genuine hostel clients will help to decide qualities they believe are essential and to contrast results and this examination.
\end{abstract}

Index Terms: Decision Making, Accommodation Process, Factor Investigation, Factor Affection.

\section{INTRODUCTION}

This research aims to investigate about the factors that effecting universities student's decision making in choosing accommodation. Also, if there is difference in the academic performance of students that are staying in on campus and off campus students housing. Some of them expected a

Revised Manuscript Received on September 22, 2019.

Zairina Ibrahim, Information Technology and Innovation Centre, Management and Science University, University Drive Seksyen 13, Shah Alam 40100, Malaysia.

Normy Rafida Abdul Rahman, Faculty Business Management and Professional Studies, Management and Science University, University Drive Seksyen 13, Shah Alam 40100, Malaysia

Md Gapar Md Johar, Information Technology and Innovation Centre, Management and Science University, University Drive Seksyen 13, Shah Alam 40100, Malaysia. single room which can be comfortable and peacefully environment while studying and some of them are looking for sharing do avoid a loneliness.

This research is to know the problems and also questions related to how and where to accommodate Students have become an issue which influence such a problem that can get so many of problem that effected their study and future. The hostel is where understudies remain for seeking after formal training far from their homes. Be that as it may, the idea of hostel isn't just restricted to place of living arrangement. Understudies take in as much as from their educators and in addition colleagues. It enhances the comprehension of the educational modules through diagnostic discourse among the understudies living in the hostels and may add to character working also [1].

The new environment are challenges to adopt by each student because it is a first time where the individual has been separated from their family as far and learning to be independently. Different individual are different mindset which is according to their age divided 2 categories matured and immature, when the individual thing maturity they can survive and accept the challenges as well which means Adjustment to New Life Whether you are a student experiencing, the campus environment for the first time or going back to the campus life after spending the vacation at home, there will be a period of adjustment, more so in the first scenario. Finding new friends some of them are friendly to take but when we are housing with senior student there are some problem started we called bully and also raging [22].

Therefore, understudies living in inns confront numerous challenges and obstacles, for example, budgetary emergencies, alteration issues, individual powerlessness, trouble, changes in eating and rest propensities, and numerous different issues. Research recommends that Empathy, unselfish behavior, emotional security will be more.

\section{A. Problem Statement}

In the beginning University resembles beginning another life. In fact, there is no study done before [17]. At the point when understudies leave home for University, they set out on another voyage, one that of confidence and self-revelation, which to a great extent takes care of business their point of view in the more extended run. Most understudies are not set up for the difficulties of college and wind up being overpowered, which results in them setting aside additional opportunity to conform to their new life. 
The new environment are challenges to adopt by each student because it is a first time where the individual has been separated from their family as far and learning to be independently. Different individual are different mindset which is according to their age divided 2 categories matured and immature, when the individual thing maturity they can survive and accept the challenges as well which means Adjustment to New Life Whether you are a student experiencing the campus environment for the first time or going back to the campus life after spending the vacation at home, there will be a period of adjustment, more so in the first scenario [1].

Finding new friends some of them are friendly to take but when we are housing with senior student there are some problem started we called bully and also raging. Housing problem such as far from our campus can effected student attending class and also join in a group assignment, Security is a first expectation to all parents whom send their daughter or son to hostel because when family is not around doesn't matter male or female individual always protected because students a normally having a cash for daily use .Security issues is can be robbery also housemates problem who can steal our property [8].

\section{B. Objective}

The main objective of this research is to explore the factors that affecting students decision making in accommodation. The following objectives are identified in order to fulfill the research case researcher have to really survey and do more research studies for the acknowledgment [21]. The objectives of this research are as follows;

a) To determine the freedom towards student decision making

b) To investigate security issue onwards student decision making

c) To understand the cleanliness issue towards student decision making.

d) To identify room sharing effeteness among student decision making

e) To identify protection issue towards student decision making

\section{LITERATURE REVIEW}

\section{A. Protection Issue}

All hostels have lockers within the rooms where you can store your things. Utilize them rather than splaying your belongings out on your bunk, as hostels are often very communal. While showering or leaving the room, always return your belongings to your locker where they can be safely stored in your absence [15]. Therefore, an organizations need to provide basic goods, facilities, services that make students highly satisfied so as to survive in highly competitive accommodation provision market. Students are far away from their family as well they should always be in secured condition whenever there are as specially at hostel such as their self-safety also the things belongings to them [9]. Thus, many of roommates are different type of behaviour some of them will use without permission the things belongings to others or spoils it as well. In my experience of hostel life there are such things happens.

\section{B. Room Sharing}

A hostel is a cheap way to lodge safely with like-minded travelers around the world. Hostels are most well-known for having dormitory-style rooms, often with bunks, along with security, social events, shared bathrooms, a common area, and a kitchen. There are 2 types of students with specific preferences which is some of them will looks for sharing room as specially the students who looking for budgeted room and some of them will looks for single room who looking for Research on student housing is diverse and has covered large areas. A vast number of studies in this area are post-occupancy surveys focusing on students' perceptions of their current environment and factors that affect their satisfaction .Room sharing being a benefits too when we share the room the price will be lower and can cover up with the budget as well because students are always been in budgeted who is depends on their family for expenses and daily use ,the risk is when we stay as sharing there will be 4 of students and room or 8 students let say it's a dorm, the things belongings to the individual not secured and the freedom to use facilities [12].

\section{Security}

An inn can make a great deal of move to make the place a protected settlement and also the explorer. For remaining safe, we suggest bringing your very own latch and an appropriate exploring pack. .The principal guideline to remain safe at inns is picking a quality lodging. Store Your Luggage. Inns as a rule have a bolted room where cumbersome packs are kept. The main individuals that approach the storage spaces are simply the inn workers, so you ought to be fine leaving a PC inside your pack for the day while you're out voyaging, particularly in the event that it doesn't fit in your locker [6].

\section{Cleanliness}

Peer reviewed research articles pertaining to cleanliness and perceptions of cleanliness were gathered using the Bowling Green State University online libraries and EBSCO host online search engine. The criteria for the literature review included: if an article discussed differences in perceptions between males and females, explored the importance of cleanliness in an environment, or evaluated attitudes surrounding cleanliness. Existing literature covers the impact of cleanliness on learning, its importance in roommate matching, cleanliness satisfaction in food and health settings, and gender differences regarding cleanliness among older adults. Cleanliness and sanitation not only play a critical role in health throughout all stages of life, but cleanliness also affects the ability to learn. Higher education institutions have cut back on spending, and the number of janitorial staff has decreased. However, cleanliness of the hostel has shown to be an integral part of learning, especially at higher education institutions. Cleaner hostels provide fewer distractions and allow students to focus on

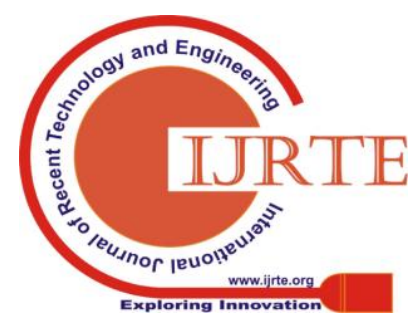


learning. Cleanliness is asked on many roommate matching questionnaires because it is usually a variable that determines whether individuals will live well together [7].

\section{E. Freedom}

Here is the definition of the Freedom what is freedom? the meaning of "freedom is the ability to you do what you want without any rejection, In his history of freedom in Western culture, Orlando opens by stating, "Freedom, like love and beauty, is one of those values better experienced than defined", many factors included for students for their freedom include sex age family income and course they have took. Some of the university students may become stress to them. The stress caused by the living endearment because some students prefer mix gender while some not feel freedom while mix with different gender on same housing area or block. They feel unable to do any activity while they mix with housing area or block with different gender. A freedom in choosing accommodation for students there are students who choose off campus accommodation to on campus due to lack of privacy sharing room or place with new students and some decide off campus accommodation for the price which is reasonable or cheaper, new housing and new accommodation with good facilities plus near to university [16]. Stating that compulsory all students must follow the rules and regulation that come from campus and any decision at university campuses "tended to work unilaterally and usually without question, and housing for these students tended to work within the same power structure with colleges instilling restriction rather than freedom and residence with appointed bounds [14].

\section{F. Conceptual Model}

A conceptual model is a representation of a system, made of the composition of concepts which are used to help people know, understand, or simulate a subject the model represents [10].

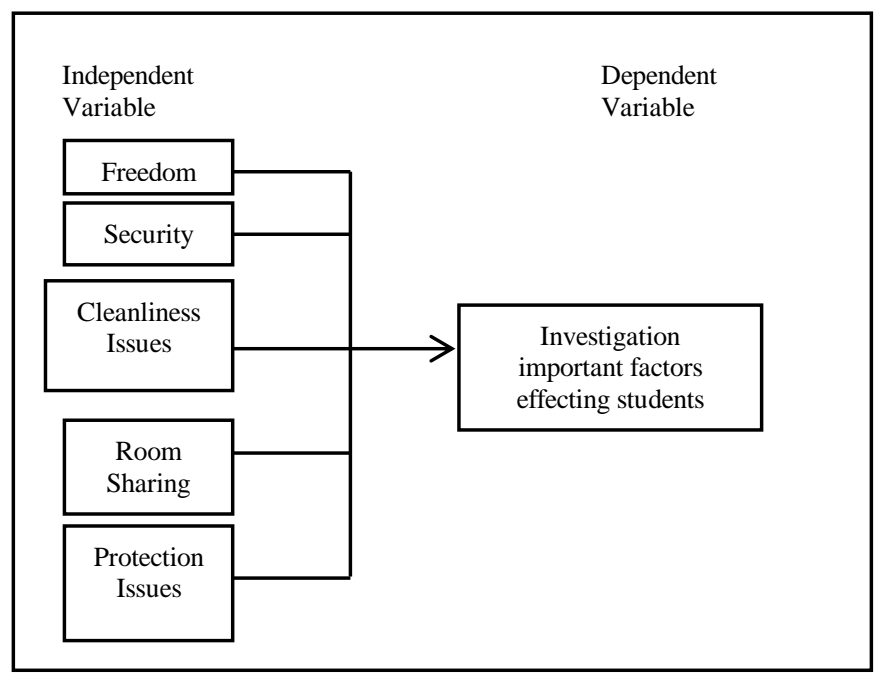

Sources: Development based on problem statement (Hollebek, 2017) Fig. 2. Theoretical Framework.

\section{METHODOLOGY}

Questionnaires are normally used as a feedback research for our chosen research topic. There are many ways to develop questionnaire, we are using multiple choice questions and close-ended questions by asking the respondent. Questionnaire is the easiest way to gather data from each and every respondent. It is also less expensive method and we can save our time compare to interview and observation method. Besides, we can gather data from many respondents in a small quantity of time [20].

This questionnaire method also easy for the respondent itself because they just need to select it. We created the questions based on our research topic and more related to investigate the important factors effecting students' decision making process accommodation. There are five steps to that we used to creating this questionnaire, first is determine the objective second is decide the attributes to measure we choose base on knowledge skills goals and demographics, third is identity audience, the audience is important to our research we need to choose the correct responded for our topic the responded is students fourth choose measurement scales the question we choose is yes or no multiple question and rank ordering, we are using the direct question then is narrative response where the responded free to give the response, lastly is check reliability to see the responded answer it correctly or not and their understand towards to question given [3].

\section{A. Research Design}

A research design is the set of methods and procedures used in collecting and analyzing measures of the variables specified in the research problem research [2]. In this research, we will implement the six basic aspect research design in order for the collection, measurement, and analysis of data. Firstly, the purpose of the study of this research is descriptive study, which means we want to ascertain and be able to describe the characteristic of the variable on interest in a situation and given research problem. We will actualize the six fundamental angle look into configuration all together for the gathering, estimation, and examination of information. Right off, the motivation behind the investigation of this exploration is engaging examination, which implies we need to determine and have the capacity to depict the normal for the variable on enthusiasm for a circumstance and given research issue [22].

Free voyagers are those vacationers who have booked just at least their transportation and convenience courses of action before takeoff on the get-away. Autonomous travel is a critical and developing division of overall. Decision of get-away schedule for the free get-away speaks to a mind boggling arrangement of choices with respect to buy of different relaxation [11].

Hostel plays a main role in student life in such variable as we mention in conceptual model has been designed. Numeric of students collected a good memories at the end and some of them fail to adopt cause of the problem has been state in problem statement because the wrongly make a

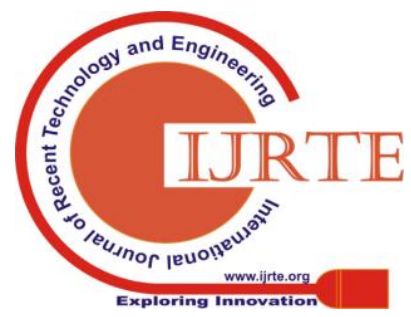


decision among choosing accommodation following by the variables has been research [13].

\section{B. Data Type and Collection Method}

There are two types of data which is primary data and secondary data. Primary data refers to informing obtained first-hand by the researcher on the variable of interest for the specific purpose of the study. Secondary data refers to information gathered from sources that already exists. In primary data individual provide information when interviewed, questionnaire or observed. Group depth interviews or focus group are another source of primary data. There are several sources of secondary data, including books, journals, etc. Researcher collect the data themselves using surveys, interviews, questionnaires and direct observation which is face to face communication. In this study the type of data used is primary data and the method of data collected is by questionnaires and face to face communication [19].

\section{Data Analysis and Technique}

Our data analysis was analyzed by using Statistical Package for Social Science (SPSS). Data analysis is an important aspect of any type of research study. Inaccurate data collection can impact the results of a study and ultimately lead to invalid results the data must be very accurate in the research. In this research study, after we have gathered our data, the data will be analyzed and organized. Furthermore, by using of SPSS useful information has been highlight, which is to answer the research question. From this SPSS software the data will be analyzed and the graph will be plot whereas the hypotheses are tested through statistical analysis using the SPSS regression model. This will determine the factors [4].

\section{RESULTS AND DISCUSSION}

The data analysis and findings based on our research. It provides statistics and data representation regarding our independent, dependant and also our moderating variables. The benefits of choosing quantitative data are will make the results reliable, valid and generalizable to a larger population. Therefore, the characteristics data is usually gathered using structured research method, the results on our target population is about 250 respondents which is lager sample size it can be repeated and valid. This chapter also study the correlate and relationships between each variable.

\section{A. Data Entry}

Data entry is the act of entering information into electronic formats by using word processing or data processing software hosted on a computer and it is data entry operators who perform these tasks' [5]. After our data collection, we used IBM SPSS Statistics to find our data of 250 respondent data recorded on IBM SPSS statistics software. The analysis different factors and variables will analysis students factor effecting decision making of students for accommodation.

\section{B. Respondents Characteristics / Attributes}

Table I: Frequency Analysis

\begin{tabular}{|c|c|c|c|}
\hline Demographic & & Frequency & Percentage \% \\
\hline \multirow[t]{3}{*}{ Gender } & Male & 111 & 44.4 \\
\hline & Female & 139 & 55.6 \\
\hline & Total & 250 & 100 \\
\hline \multirow[t]{5}{*}{ Age } & $20-23$ & 174 & 69.6 \\
\hline & $24-26$ & 64 & 25.6 \\
\hline & $27-30$ & 8 & 3.2 \\
\hline & $>31$ & 4 & 1.6 \\
\hline & Total & 250 & 100 \\
\hline \multirow[t]{4}{*}{ Race } & Malay & 144 & 57.6 \\
\hline & Indian & 83 & 33.2 \\
\hline & Chinese & 23 & 9.2 \\
\hline & Total & 250 & 100 \\
\hline
\end{tabular}

\section{Respondents Behaviour}

Descriptive statistics are numbers that are used to summarize and describe data. The word data refers to the information that has been collected from an experiment, survey, a record [5].

\begin{tabular}{|l|l|l|}
\hline Trotection & Mean & Standard Deviation \\
\hline Protection 1 & 3.68 & 0.983 \\
\hline Protection 2 & 3.90 & 0.937 \\
\hline Protection 3 & 3.70 & 1.068 \\
\hline Protection 4 & 3.89 & 0.920 \\
\hline
\end{tabular}

According to Table above, in general the Mean value shows that all of the questions are 3 and above which means that most of the respondents are neutral and above to the questions given. The highest Mean is protection 2, followed by protection 4 . All of the variables stated above did not show any much difference, which range from between 3.68 to 3.9 only.

Table III: Descriptive Test for Cleanliness

\begin{tabular}{|l|l|l|}
\hline Cleanliness & Mean & Standard deviation \\
\hline Cleanliness 1 & 3.59 & 1.127 \\
\hline Cleanliness 2 & 3.68 & 0.967 \\
\hline Cleanliness 3 & 3.40 & 1.212 \\
\hline Cleanliness 4 & 3.62 & 1.121 \\
\hline
\end{tabular}

Descriptive test shows highest mean value is cleanliness 2 (Facilities provided at hostel) and the lowest mean value is cleanliness 4 mean, There are 0.28 difference between the highest mean and lowest. 


\begin{tabular}{|l|l|l|}
\hline Security & Mean & Standard deviation \\
\hline Security 1 & 3.78 & 1.025 \\
\hline Security 2 & 3.81 & 1.014 \\
\hline Security 3 & 3.74 & 1.115 \\
\hline Security 4 & 3.81 & 1.081 \\
\hline
\end{tabular}

Descriptive test stating security 2 and security 4 have the same mean value and both have highest mean value among others. Security 3 is with lowest mean value.

Table V: Descriptive for Freedom

\begin{tabular}{|l|l|l|}
\hline Freedom & Mean & Standard deviation \\
\hline Freedom 1 & 3.65 & 1.096 \\
\hline Freedom 2 & 3.59 & 1.169 \\
\hline Freedom 3 & 3.69 & 1.101 \\
\hline Freedom 4 & 3.36 & 1.382 \\
\hline
\end{tabular}

For mean descriptive test, the highest is 3.69 and lowest is 3.36 and second highest is 3.65 (24 hours can in and from hostel)

Table VI: Descriptive Test for Room Sharing

\begin{tabular}{|l|l|l|}
\hline Room sharing & Mean & Standard deviation \\
\hline Room 1 & 3.62 & 1.246 \\
\hline Room 2 & 3.60 & 1.152 \\
\hline Room 3 & 3.52 & 1.166 \\
\hline Room 4 & 3.73 & 1.194 \\
\hline
\end{tabular}

For this room sharing test, highest mean is Room 4(3.73), secondly is room 1(3.62) and least is Room3 (3.52).

Table VII: Descriptive Test for Accommodation

\begin{tabular}{|l|l|l|}
\hline Accommodation & Mean & Standard deviation \\
\hline Accommodation 1 & 1.02 & 0.126 \\
\hline Accommodation 2 & 1.08 & 0.266 \\
\hline Accommodation 3 & 1.08 & 0.278 \\
\hline Accommodation 4 & 1.04 & 0.196 \\
\hline Accommodation 5 & 1.01 & 0.109 \\
\hline
\end{tabular}

Accommodation test shows accommodation 2 and accommodations 3 have the highest mean value whereas accommodation 5 has the lowest mean value.

\section{Hypothesis Testing}

Table VIII: Reliability Test

\section{Reliability Statistics}

\begin{tabular}{|l|c|}
\hline Cronbach's Alpha & \\
\hline Protection & 0.831 \\
\hline Cleanliness & 0.812 \\
\hline Security & 0.817 \\
\hline Freedom & 0.781 \\
\hline Room sharing & 0.702 \\
\hline Accommodation & 0.730 \\
\hline
\end{tabular}

Our data shows $>0.7$ value for six variables in reliability test which indicates that our data is very reliable (protection, cleanliness, security, freedom, room sharing and accommodation).

\begin{tabular}{|c|c|c|c|c|c|c|c|}
\hline & & $\begin{array}{l}\text { Protectio } \\
n\end{array}$ & $\begin{array}{l}\text { Cleanline } \\
\text { ss }\end{array}$ & Security & Freedom & Room & Accommodation \\
\hline & & & & & & \\
\hline \multicolumn{2}{|c|}{$\begin{array}{r}\text { Protection Pearson } \\
\text { Correlat }\end{array}$} & 1 & $.632^{* *}$ & $.515^{* *}$ & $425^{* *}$ & $388^{* *}$ & .072 \\
\hline & $\begin{array}{l}\text { Sig. } \\
\text { (2-tailed }\end{array}$ & & .000 & .000 & .000 & .000 & .256 \\
\hline & & & & & & & \\
\hline & $\mathrm{N}$ & 250 & 250 & 250 & 250 & 250 & 250 \\
\hline \multicolumn{2}{|c|}{ Cleanlines Pearson } & & & & & & \\
\hline & $\begin{array}{l}\text { Correlat } \\
\text { ion }\end{array}$ & $.632^{* *}$ & 1 & $.628^{* *}$ & $.545^{* *}$ & $.532^{* *}$ & $.137^{*}$ \\
\hline & $\begin{array}{l}\text { Sig. } \\
\text { (2-tailed }\end{array}$ & .000 & & .000 & .000 & .000 & .030 \\
\hline & ) & & & & & & \\
\hline & $\mathrm{N}$ & 250 & 250 & 250 & 250 & 250 & 250 \\
\hline \multirow[t]{5}{*}{ Security } & $\begin{array}{l}\text { Pearson } \\
\end{array}$ & & & & & & \\
\hline & Correlat & $.515^{* *}$ & $.628^{* *}$ & 1 & $.494^{* *}$ & $.496^{* *}$ & \\
\hline & Sig. & & 0 & & 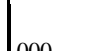 &  & 140 \\
\hline & ) & .000 & .000 & & & .000 & \\
\hline & $\mathrm{N}$ & 250 & 250 & 250 & 250 & 250 & 250 \\
\hline \multirow[t]{6}{*}{ Freedom } & Pearson & & & & & & \\
\hline & Correlat & $.425^{* *}$ & $.545^{* *}$ & $494^{* *}$ & 1 & $.606^{* *}$ & $.164^{* *}$ \\
\hline & Sig. & & & & & & \\
\hline & (2-tailed & .000 & .000 & .000 & & .000 & .009 \\
\hline & ) & & & & & & \\
\hline & $\mathrm{N}$ & 250 & 250 & 250 & 250 & 250 & 250 \\
\hline \multirow[t]{6}{*}{ Room } & Pearson & & & & & & \\
\hline & Correlat & $388^{* *}$ & $388^{* *}$ & $.532^{* *}$ & $496^{* *}$ & $606 "$ & 1 \\
\hline & Sig. & & & & & & \\
\hline & (2-tailed & .000 & .000 & .000 & .000 & .000 & \\
\hline & ) & & & & & & \\
\hline & $\mathrm{N}$ & 250 & 250 & 250 & 250 & 250 & 250 \\
\hline \multirow{5}{*}{$\begin{array}{l}\text { Accommo } \\
\text { dation }\end{array}$} & Pearson & & & & & & \\
\hline & $\begin{array}{l}\text { Correlat } \\
\text { ion }\end{array}$ & .072 & $.137^{*}$ & .092 & $.164^{* *}$ & $.141^{*}$ & 1 \\
\hline & Sig. & & & 140 & 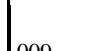 & 026 & \\
\hline & ) & & & & & & \\
\hline & $\mathrm{N}$ & 250 & 250 & 250 & 250 & 250 & 250 \\
\hline
\end{tabular}

The Pearson's Correlation will make to measure the relationship between every variable, example 0.8 and 1 means the strong relationship between them, 0.41 and 0.60 will become moderate, 0.21 and 0.40 are weak and no relationship the relationship between 0.0 and 0.2 . The positive sign between the variables indicate is positively correlated each other.

Our Independent variables are positively correlated with dependant variables which shows that all of our hypothesis between independent and dependant variables are accepted. It show protection, cleanliness, security, freedom, room and accommodation have positive or less negative influence to the students decision making. 


\section{CONCLUSION}

According to our research aims in future based on conceptual model has research and hypothesis test .Students should consider with choosing accommodation, make sure the accommodation has choose is secured ,clean, protected, freedom from positive term and also make sure the room sharing is good behaviour and also can be independently choose single room based on preferences and comfortable [23].

As research along the duration has given, data has been collected using survey form, the method has use for collected students information is easily to communicate with respondent, when the survey form has distribute with respondent some of them told the issue has been faced and also there are chances to share the current issue has faced .

According to the research topic "Investigating important factors effecting students' decision making process accommodation". Respondent that aims is 250 students who just entered the university environment. Aims to focus on new student is as researched, junior students failed to adopt the new challenges environment and the mainly cause is wrong decision among choosing the accommodation, some of the environment different in term of security ,freedom, cleanliness ,room sharing(mix with senior)and protection issue.

To reaching the problem statement, data has been collected by using survey, the respondent is all the students staying at hostel Male and Female according to the demographic. Our data shows $>0.7$ value for six variables in reliability test which indicates that our data is very reliable (protection, cleanliness, security, freedom, room sharing and accommodation) [18].

For race, most of them are Malays with 57\% (144 respondents) but there is a bit difference with the Indian, showing $33.2 \%$ (83 respondents) of the total respondents. And the rest is Chinese made up $9.2 \%$ (23 respondents). It is tally with our percentage because University Students consist about $60 \%$ of Malays and the rest is Indian and Chinese.

\section{REFERENCES}

[1] Alnajem, O.M., and Mohamad. N. 2018. Hostel Front Desk Employees' Perception.

[2] Angell. E., Maureen. B., Stoner, Julia, and Shelden. L, Debra. 2009. Trust in Education Professionals: Perspectives of Mothers of Children With Disabilities. Remedial and Special Education.

[3] Backflies, E. 2018. A Survey of UK.

[4] Baraldi, E., and Bocconcelli, R. 2001. The Quantitative Journey in a Qualitative Landscape: Developing a Data Collection Model and a Quantitative Methodology in Business Network Studies. Uppsala University and University of Urbino. Management Decision. 39(7), 564-577.

[5] Bougie, R., and Sekaran, U. 2016. Research Method for Business: A Skill Building Approach.

[6] Clarkson. M, Wanie, Emmanuel, E.E., Oben, J. M. M., and Ivo, T. T. 2001. Youth Advocacy for Efficient Hostel Management and Affordable University Students' Housing in Buea, Cameroon. International Journal of Housing Markets and Analysis. 10(1), 81-111.

[7] Chitty, B., Ward, Steven., and Chua, C. 2007. An application of the ECSI model as a predictor of satisfaction and loyalty for backpacker hostels. Marketing Intelligence \& Planning. 25(6), 563-580.

[8] Costa, M. V., and Carlos. 2018. Do Hostels Play a Role in Pleasing.

[9] Doughty, K. 2018. The Role of Digital Technologies in Outcome-based Commissiong. Univeristy of Cumbria. Director of The i-Centre for Usable Home Technology (iCUHTec).
[10] Hollebeek, L., Juric, B. and Tang, W. 2017. Virtual brand community engagement practices: A refined typology and model. Journal of Services Marketing. 31(3), 204-217.

[11] Hynes, G. E. 2012. Improving Employees' Interpersonal Communication Competencies: A Qualitative Study. Business Communication Quarterly, 75(4), 466-475.

[12] Kajimo-Shakantu, K., Opawole, A., and Alao, O. O., and Ogbaje, C. P. 2018. Risk Factors Associated with Procuring University Hostel Facilities through Build-Operate-Transfer Model. Journal of Engineering, Design and Technology. 17(1), 136-154

[13] Kan, C.W., and Lau, M. P. 2018. Effects of Sampling Methods on Detection of Yarn Quality. Research Journal of Textile and Apparel. 11(4), 71-79.

[14] Karban, K., Paley, C., and Willcock, K. 2018. Towards Support: Evaluating a Move to Independent Living. University of Bradford.

[15] McCreadie, C. 2018. No Secrets: guidance in England for the protection of vulnerable adults from abuse. The Journal of Adult Protection. 2(3), 4-16.

[16] Muggleton, T. H., and Ruthven, I. 2012. Homelessness and access to the informational mainstream. Journal of Documentation. 68(2), 218-237.

[17] National University of Malaysia (UKM). 2018. Retrieved from http://www.ukm.my/ptsl/?s=hostel+issue

[18] Opawole, A., Fernando, S., Kajimo-Shakantu, K., and Ogbaje, C. P. 2018. Exploring public private partnership as an alternative housing delivery model in Namibia.

[19] Perera, T., and Liyanage, K. 2018. Methodology for Rapid Identification and Collection of Input Data in The Simulation of Manufacturing Systems. Simulation Practice and Theory. 7, 645-656.

[20] Shurrab, M., Ghaleb Abbasi, Razan A. K. 2018. Evaluating the effect of motivational dimensions on the construction project managers in Jordan. Engineering, Construction and Architectural Management. 25(3), 412-424.

[21] Stoner, J. B. 2018. Qualitative research in education: Other methods of seeking knowledge.

[22] Yang, Yefei, \& Lau, Antonio, and Lee. K.C., Peter, and Yeung. C.L., Andy and Cheng, T. C. E. 2018. Efficacy of China's strategic environmental management in its institutional environment. International Journal of Operations \& Production Management. 39

[23] Weerasinghe, I.M.S., Lalitha, R., and Fernando, S. 201. University Facilities and Student Satisfaction in Sri Lanka. International Journal of Educational Management. 32(5), 866-880.

\section{AUTHORS PROFILE}

I am Zairina Ibrahim, I am associated with Information Technology and Innovation Centre, Management and Science University, University Drive Seksyen 13, Shah Alam 40100, Malaysia and my area of interest is leadership and management.

I am Normy Rafida Abdul Rahman, I am from Faculty Business Management and

Professional Studies, Management and Science University, University Drive Seksyen 13, Shah Alam 40100, Malaysia and my area of interest is leadership and management.

I am Md Gapar Md Johar, I am associated with Information Technology and Innovation Centre, Management and Science University, University Drive Seksyen 13,

Shah Alam 40100, Malaysia my area of interest is leadership and management. 